\title{
Sawfish captures in the Queensland Shark Control Program, 1962 to 2016
}

\author{
Barbara E. Wueringer* \\ Sharks And Rays Australia, PO Box 575, Bungalow, Qld 4870, Australia
}

\begin{abstract}
Within the Great Barrier Reef World Heritage Area in Queensland, Australia, lack of information on the distribution of sawfishes presents difficulty for informed management of their habitats and populations. This study aims to provide insights into the historical and current distributions through analysis of sawfish by-catch records from the Queensland Shark Control Program (QSCP), which has protected bathers since 1963 by targeting large sharks. Sawfishes have been caught in 8 of the 10 areas where the QSCP has been active. A total of 1450 captures of sawfishes (all 4 species known from Australia) were reported from 1963 to August 2016, with most (>99\%) in the 4 most northern areas; Cairns, Townsville, Mackay, and Rockhampton. Sawfishes were mainly captured in gillnets. Most (95.4\%) animals were alive when the gear was checked. In Townsville and Rockhampton, standardised sawfish captures have declined over the years. No sawfish captures in QSCP gear have been recorded in 3 areas (Cairns, Townsville, Rockhampton) since gillnets were banned there, but in Mackay, where gillnets are still used, only 4 animals have been caught since 1999. It is recommended that QSCP contractors take more detailed data of future sawfish captures, and that contractors and fishers receive training on releasing sawfishes swiftly and with minimal damage. Moreover, as the use of gillnets in the QSCP has been decreasing over the years, fisheries-independent studies of current sawfish distributions are required.
\end{abstract}

KEY WORDS: Elasmobranch $\cdot$ Pristis $\cdot$ Anoxypristis $\cdot$ By-catch $\cdot$ Australia

\section{INTRODUCTION}

Sawfishes are the most endangered family of sharks and rays in the world (Dulvy et al. 2014). Since the beginning of the $20^{\text {th }}$ century, range contractions have been severe in all 5 species: the smalltooth sawfish Pristis pectinata has disappeared from $81 \%$ of its former range, while range contractions of the other species of sawfish have been less severe (dwarf sawfish Pristis clavata: $70 \%$; largetooth sawfish P. pristis: $61 \%$; green sawfish $P$. zijsron: $38 \%$; narrow sawfish Anoxypristis cuspidata: $30 \%$; Dulvy et al. 2016). All species are listed on the IUCN Red List as Endangered or Critically Endangered (IUCN 2006). In Australia, 3 of the 4 species (P. pristis, $P$. clavata and $P$. zijsron) are listed as vulnerable and migratory on the Environment Protection and Biodiversity Conserva-

${ }^{*}$ Corresponding author: b.wueringer@gmail.com

$\S_{\text {Corrections were made after publication. For details see }}$ www.int-res.com/abstracts/esr/v34/c_p293-300/ This corrected version: October 20, 2017 tion (EPBC) Act of 1999, while the fourth species (A. cuspidata) is listed as migratory. In Queensland, all sawfishes are protected and must be released as quickly as possible if accidentally caught (Queensland Fisheries Act of 1994).

Australian sawfish populations have fared better than those in the rest of the world, and Northern Australia, including the Gulf of Carpentaria, is considered one of the last strongholds of sawfishes in the world (Peverell 2005). In the waters of the Gulf of Carpentaria and along Queensland's east coast, all 4 species of sawfish interact with various commercial fisheries, such as the Northern Prawn Fishery and the Inshore Fin Fish Fishery. Comparison of 2 data sources for the Gulf of Carpentaria Inshore Fin Fish Fishery (commercial logbook data versus data collected by fisheries observers) before the state-wide

(C) The author 2017. Open Access under Creative Commons by Attribution Licence. Use, distribution and reproduction are unrestricted. Authors and original publication must be credited. 
protection of sawfishes suggests a high degree of under-reporting of sawfish captures (Department of the Environment 2014). However, the state-wide fisheries observer program was abolished in 2013. It is unclear how widespread the practise of amputating the saw of sawfish before releasing them is (Morgan et al. 2016). Saw-less, live sawfish have recently been observed in Western Australia (Morgan et al. 2016) and Queensland waters (pers. obs.) but have been observed in the USA for over a decade (see Seitz \& Poulakis 2006 for details).

The distributions and abundances of sawfishes in Queensland waters have only been assessed in the Gulf of Carpentaria (Peverell 2009), along Queensland's west coast. Within the Great Barrier Reef Marine Park (GBRMP), which covers coastal and state marine waters north of Bundaberg to the tip of Cape York, at least 3 but potentially all 4 sawfish species occur in small numbers (Department of the Environment 2014). At present, the distribution of $P$. pristis within the GBRMP is considered discontinuous and potentially restricted to Princess Charlotte Bay (see Fig. 1), but it is not clear if the discontinuity of records reflects an absence of sampling effort (Department of the Environment 2014). Current populations of $P$. zijsron on Queensland's east coast are considered to be 'near the edge of the species' range' and the Great Barrier Reef Marine Park Authority thus regards it 'a priority to identify where this species still occurs' (GBRMPA 2012). P. clavata may have been historically present on the east coast of Queensland, but there is no confirmed recent record of this species (Department of the Environment 2014, S. Peverell pers. comm.). Moreover, the distribution of both A. cuspidata and $P$. zijsron within the GBRMP are mainly known from fishery observer data from sites distributed around Townsville (south of Cairns) (Harry et al. 2011), as no fisheries observer coverage ever existed north of Cooktown. This lack of information presents difficulty for informed management of sawfish habitats and populations within the GBRMP (GBRMPA 2012).

The aims of the present study were to provide insights into the historic and current distributions and relative abundances of sawfishes in waters along the Queensland east coast through analysis of sawfish by-catch records from the Queensland Shark Control Program (QSCP). This ongoing program, which aims to protect bathers in Queensland waters, targets large specimens of selected shark species that pose a potential threat to humans, such as the white shark Carcharodon carcharias, the tiger shark Galeocerdo cuvier and the bull shark Carcharhinus leucas (Paterson 1990). Since its inception, the QSCP has used a mixed-gear strategy (Gribble et al. 1998), composed of baited drum lines and non-baited gillnets. The gear remains in the water year-round and is not removed during the off-season or during winter (Gribble et al. 1998). The nets (186 m long, $6 \mathrm{~m}$ deep, $50 \mathrm{~cm}$ stretched mesh, material venetian-blind cord) are set parallel to the shore, at a distance of around $500 \mathrm{~m}$ from shore according to local bathymetry and to avoid swimmer interactions (Gribble et al. 1998). Each drum line has a single 14/0 hook (Holmes et al. 2012). Contractors check nets and drum lines 15 to $20 \mathrm{~d} \mathrm{mo}^{-1}$ (Holmes et al. 2012).

The program commenced in Queensland in 1962 (Paterson 1990) and is currently active in 10 coastal areas, which differ in commencement date and gear type (Fig. 1). In all locations, a mixed-gear strategy with gillnets and drum lines was used from the beginning, apart from Bundaberg, where only gillnets were deployed from 1974 until 1976, and Gladstone, where gillnets were never used. The most northern

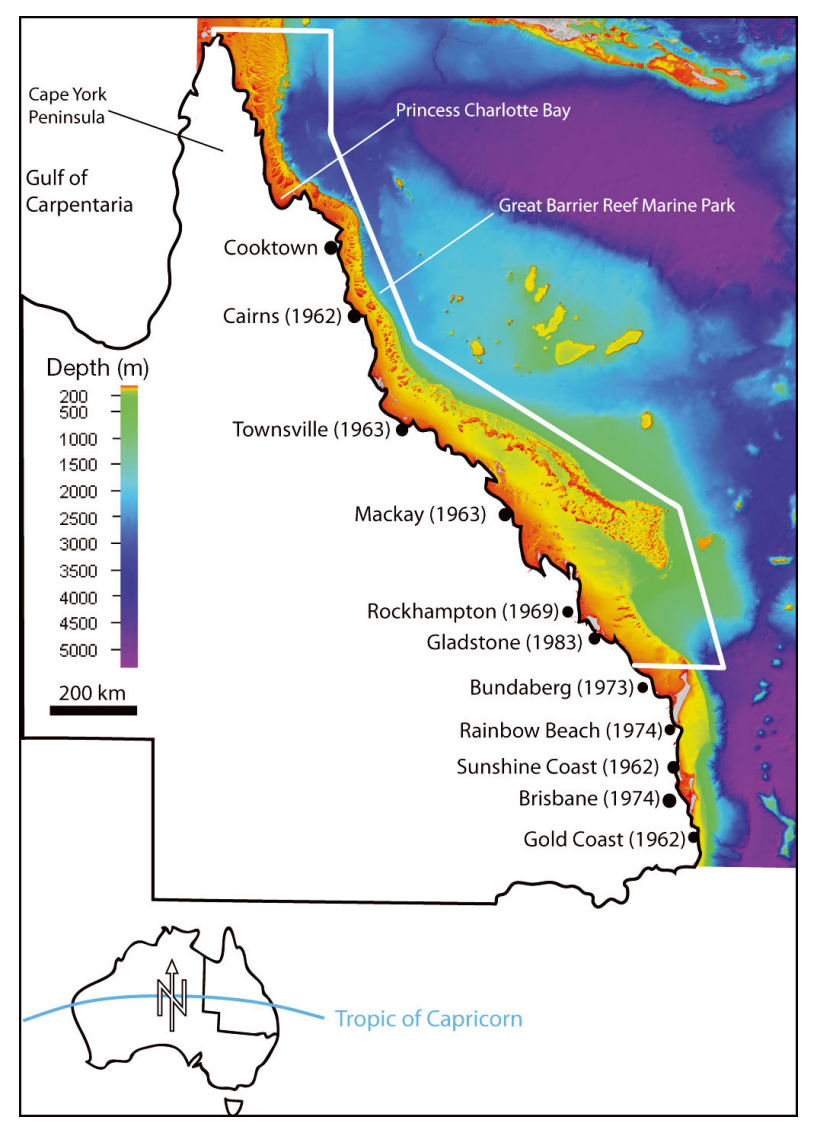

Fig. 1. Queensland, Australia depicting localities where the Queensland Shark Control Program is currently active. The year given at each locality indicates the first year the program became active. Average depth of inshore areas in the Great Barrier Reef Marine Park is around $30 \mathrm{~m}$. Bathymetric data adapted from Beaman (2010) 
location of the QSCP is Cairns, and no locations in the Gulf of Carpentaria are targeted, as the QSCP only operates in human population centres.

\section{MATERIALS AND METHODS}

Data from the QSCP were provided by the Department of Agriculture and Fishing, and include captures since the program's inception through August 2016. All capture data of the program since 2001 are also freely available on the department's website ${ }^{\mathbf{1}}$. Additionally, a list of gear changes over the years was received. Data prior to mid-1996 contained duplicated entries whose validity was unknown (J. Krause [Manager QSCP] pers. comm.). The data were verified in Microsoft Excel 2011 for Mac, and imported to IBM SPSS Statistics v.21 for statistical analyses. Within the data and this publication, an 'Area' was defined as a locality/city where QSCP gear was deployed, e.g. Townsville, Bundaberg, or Cairns. Each 'Area' was further divided into 'Locations', which were specific beaches where sampling gear was located.

\section{QSCP data limitations}

Changes in deployed gear over time for the different locations were identified for the 8 locations where sawfishes had been caught (for details see Supplement 1 at www.int-res.com/articles/suppl/n034 p293_supp.pdf). Even though the QSCP only ever used 2 types of gear (gillnets and drum lines), sawfish captures were recorded in 3 gear categories, namely 'Gillnet', 'Drum line' and 'Other'. Data in these categories were treated separately, and it was assumed that 'Other' contained catches from both gillnets and drum lines (J. Krause pers. comm.).

Duplicate data entries were identified, and only marked as such if every entry associated with the capture was identical (species, area, location, date, size [if available], capture gear, state: 'Alive' or 'Dead'). Duplicates were excluded from further analysis, as an initial analysis (see Supplement 2 at www.int-res.com/ articles/suppl/n034p293_supp.pdf) could not identify if they represented (1) invalid duplicates of data entries that occurred over time, or (2) valid data entries indicating that multiple sawfish were captured in the same gear on the same day.

\footnotetext{
${ }^{1}$ https://www.daf.qld.gov.au/fisheries/services/shark-controlprogram
}

Contractors of the QSCP identified sawfishes according to the following categories: from 1962 until 1996, 'Sawfish(Ray)' was the only category that existed in the data, indicating that sawfishes were only identified to the family level (Pristidae). From 1996 onwards, 4 categories existed, namely 'Sawfish(Ray)', 'Narrow sawfish' (=Anoxypristis cuspidata), 'Green sawfish' (=Pristis zijsron), and 'Queensland sawfish' (=local common name of the dwarf sawfish, Pristis clavata). To investigate the effect of the QSCP on endangered species, the program was reviewed by 2 Ministerial Committees in 1992 and 1996, and in 1992 it was recommended that operators were trained to identify catches to species level (Gribble et al. 1998). It is thus highly likely that from 1996 onwards the category 'Sawfish(Ray)' represents the largetooth sawfish P. pristis. However, as species identification skills of contractors cannot be verified, and only a single $P$. zijsron and P. clavata were reported each, the present analysis considers 'Sawfish(Ray)' to represent Pristis spp. In Australia, where P. pristis is known as the freshwater sawfish, the long-held belief that this species is stenohaline could have led to misidentifications of adult specimens from marine waters (Wueringer et al. 2009). Narrow sawfish is considered to be Anoxypristis, whose common name is narrow sawfish, and which is easily differentiated from Pristis spp. by its flattened rostral teeth and denticle-free skin in juveniles (Wueringer et al. 2009). Data in the 'Tropical sawshark' category (from 1974 to $1997, \mathrm{n}=29$ ) were excluded from the present analysis, as they only occurred in southern locations (Rockhampton, Rainbow Beach, Sunshine Coast) and likely represent sawsharks (Pristiophoridae).

Some contractors recorded total lengths (TL) of captured sawfishes $(\mathrm{n}=76)$. As the length was recorded in $\mathrm{m}$, the validity of some entries is doubtful; for example early records from 1969 contain sawfish lengths of 14.03 or 16.02 , which appear improbably large, while later entries in the 1990s record lengths of 1.02, which appear overly accurate. It is likely that early entries are in feet, as Australia only converted to the metric system in 1969, but given that the changeover was only officially completed across all sectors in 1988, lengths of captured sawfish were not further analysed. Contractors recorded no other biological data.

\section{Fishing effort and catch rate standardisation}

Standardised catch rates were not calculated for Mackay or Cairns, as a large proportion of early 
catches in these areas were recorded in the gear category 'Other' (see Fig. 2), which contained data from both gillnets and drum lines. Standardised catch rates were not calculated for sawfish captures on drum lines, as they were negligible (see 'Results'). The annual catch effort was calculated separately for 2 areas (Rockhampton and Townsville), as gillnet days per year according to the method of Simpfendorfer (1992) and Holmes et al. (2012). Catch rates for the same areas were standardised as follows: annual frequencies of sawfish captures (of all species categories merged) in gillnets were calculated and divided by the respective annual sampling effort (multiplied by $10^{5}$ for ease of presentation).

\section{RESULTS}

Since 1963, sawfishes have been caught in 8 of the 10 areas in Queensland where the QSCP was active. A total of 1450 sawfishes were captured through August 2016. No sawfish has ever been caught near Gladstone or Brisbane/North Stradbroke Island. Only a fraction of all sawfish captures $(0.5 \%)$ occurred in the 4 southern areas of Bundaberg, Rainbow Beach, the Sunshine Coast and the Gold Coast. Most (99.5\%) captures occurred in the 4 northern areas of Cairns, Townsville, Mackay, and Rockhampton (Fig. 2). Most $(95.4 \%)$ sawfishes were captured alive, while the rest were recorded as dead. Only $0.4 \%$ of all captures occurred on drum lines, while $49.9 \%$ occurred in gillnets and $49.7 \%$ were recorded in the category 'Other'. Between 1962 and 1995, sawfishes were only identified to Family level.

Since 1996, when data became more detailed, 94.3\% of all captures occurred in gillnets, none occurred on drum lines, and only $5.7 \%$ were recorded as 'Other'. The QSCP has caught 88 sawfishes since 1996 (Fig. 3), the majority of which were narrow sawfish Anoxypristis cuspidata $(59.1 \%)$ followed by Pristis spp. $(38.6 \%)$. Only 1 specimen each of green sawfish Pristis zijsron and dwarf sawfish P. clavata were recorded, which were captured in 2004 off Mackay and in 2003 off Cairns, respectively (Fig. 3). Both specimens were alive. In December 2011, a female A. cuspidata (2.5 m TL) caught at Trinity Beach off Cairns was observed to give birth. The position of capture in the gill net was recorded for 67 sawfishes since 1996; the majority $(94.0 \%)$ were captured near the bottom of the net, while $6.0 \%$ were captured closer to the top.

The QSCP data set contained 147 data entries that were duplicated 223 times. Duplicates were limited to the years before 1996, and occurred in 6 areas (see
Supplement 2 for details). A 1-sample chi-squared test was conducted to assess whether duplicates were equally frequent across all locations. The results of the test were significant $\left(\chi^{2}(20, N=121)=\right.$ $122.802, \mathrm{df}=19, \mathrm{p}<0.01$ ) indicating that duplicates occurred more frequently in some sampling locations. Most duplicates occurred in Horseshoe Bay (Magnetic Island, Townsville; $\mathrm{n}=28$ ). Duplicates were either associated with 'Other' fishing gear (57.8\%), or gillnets $(42.2 \%)$.

Plotting of catch frequencies for 4 areas (Fig. 2) indicated that in Cairns and Mackay, most of the early sawfish captures were recorded in 'Other' gear (= gillnets and drum lines), especially during the early decades of the program. Sawfish catches peaked off Cairns shortly after the program commenced. No

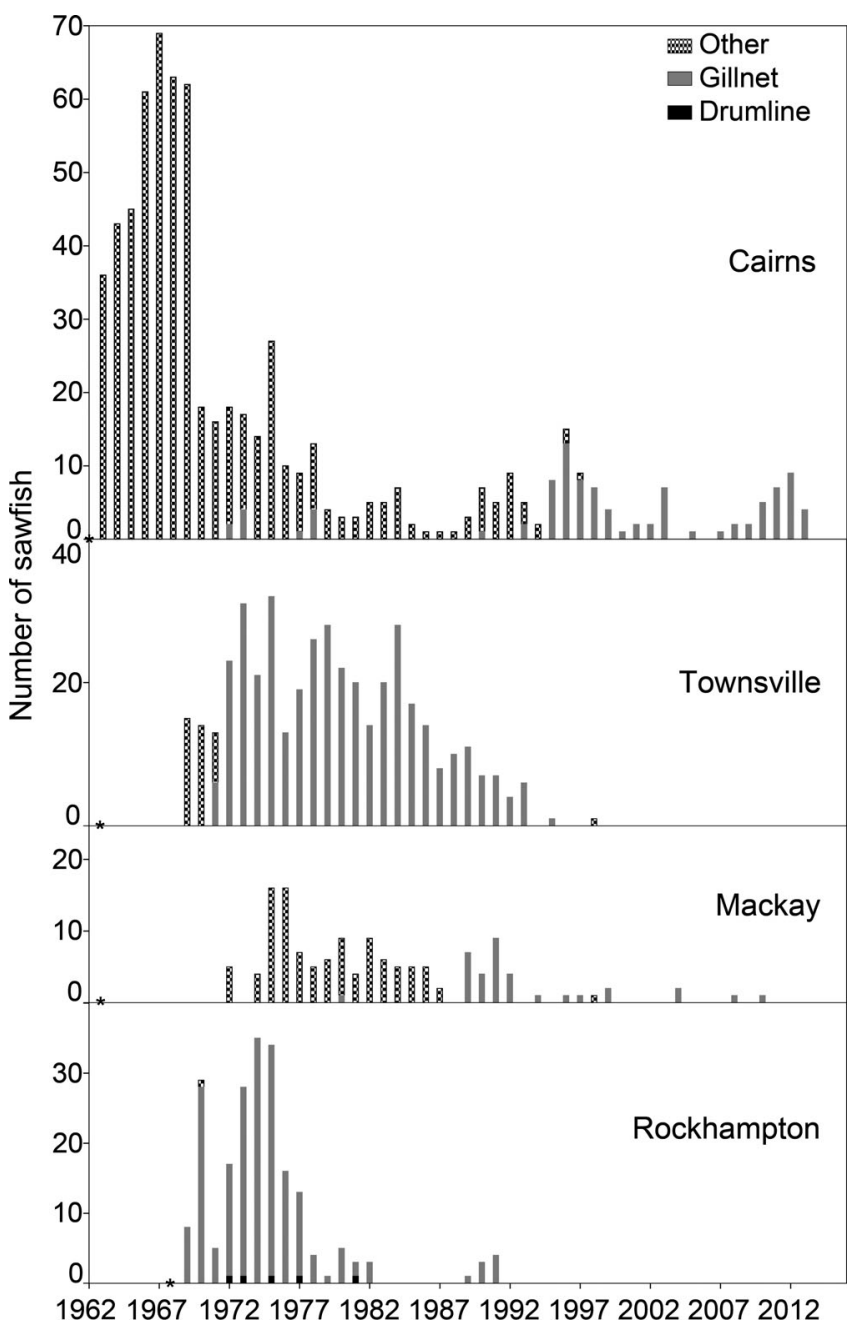

Fig. 2. Capture frequencies for sawfishes by gear type recorded in the Queensland Shark Control Program (QSCP) for 4 areas listed from north to south: Cairns, Townsville, Mackay and Rockhampton. ( $\left.{ }^{*}\right)$ indicates the local program commencement year 
QSCP gillnets were installed off Cairns from 1981 to 1993, but 23 drum lines were present. In Mackay, no sawfish catches were recorded for the first 9 years of the program, even though up to 24 drum lines and 7 gillnets were present during this time. During this

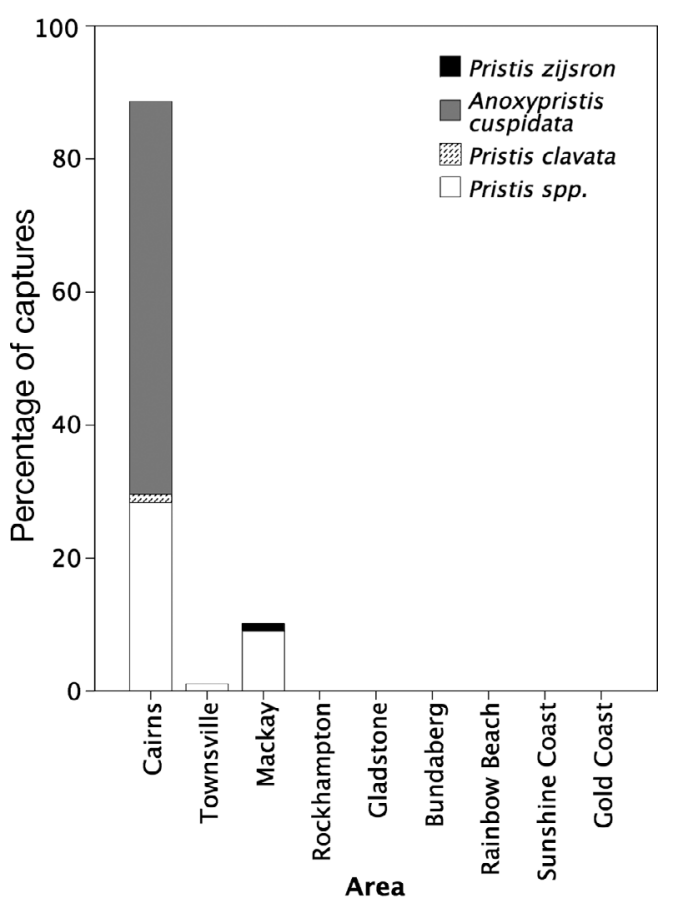

Fig. 3. Capture frequencies plotted as percentage of overall captures $(\mathrm{n}=88)$ since 1996 in the Queensland Shark Control Program listed by area and taxa

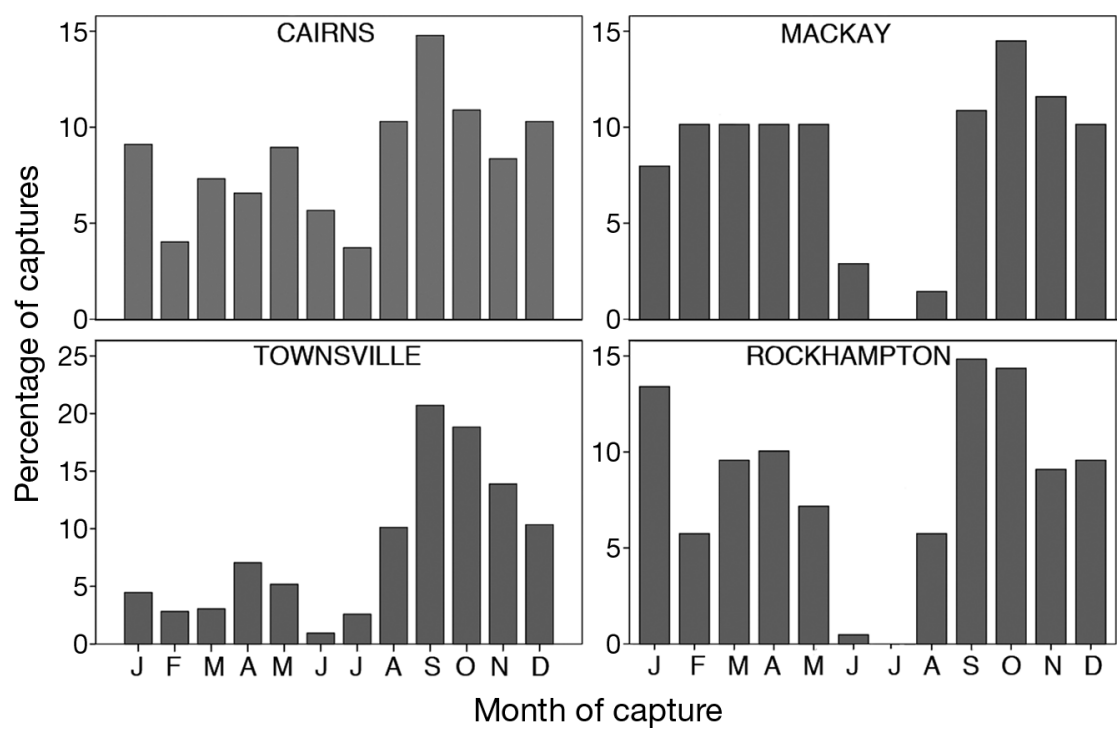

Fig. 4. Capture frequencies for sawfishes captured in the Queensland Shark Control Program in any gear type plotted as percentage of total captures for each area per month. In Cairns and Townsville, sawfishes were present yearround, while in Mackay and Rockhampton none were captured in July. Note the scale difference for Townsville time, gear was only deployed part-time. No sawfish captures in QSCP gear have been recorded in Cairns since 2013, Townsville since 1999, Mackay since 2010, and Rockhampton since 1991. These numbers appear to coincide with the removal of gillnets in 3 areas (Cairns July 2013, Townsville 1999, Rockhampton 1992), while in Mackay 5 gillnets are still active. Sawfish captures on drum lines were only ever recorded off Rockhampton.

Capture frequencies for sawfishes caught in all gear categories were plotted as percentage of total captures for each area per month (Fig. 4). As catch percentages were not standardised over the fishing effort, interpret these data with caution. However, sawfishes appear to have been present in all areas year-round, with a slight decrease in all 4 locations over the winter months.

\section{Standardised catch rates}

Annual fishing effort and standardised catch rates were calculated for sawfishes captured in gillnets off Townsville and Rockhampton, where 29.3 and $14.4 \%$ of all sawfishes were captured, respectively. In Townsville, no sawfish were caught for the first $8 \mathrm{yr}$ of the program, and the use of gillnets as part of the QSCP was steadily reduced over the years (Fig. 5). Sawfish catches remained high during the 1970s and 1980s in Townsville (1970s standardised catch rate [mean \pm $\mathrm{SD}]: 983.3 \pm 529.0 ; 1980$ s standardised catch rate: $1065.8 \pm 391.9$; Fig. 6), but dropped after 1986 (1990s standardised catch rate: $278.5 \pm 339.3$; Figs. 5 \& 6). Since 1996, no sawfish have been caught in gillnets off Townsville. A Jonckheere-Terpstra test for ordered alternatives indicated that there was a significant trend of decreasing standardised catch rates over the decades off Townsville $\left(T_{\mathrm{JT}}=96.00, z=-5.094\right.$, $\mathrm{p}<0.01)$.

Sawfish captures in Rockhampton peaked shortly after local commencement of the program (1970s standardised catch rate: $868.5 \pm 603.1$ ), but remained lower than those off Townsville. No sawfish were caught in gillnets off Rockhampton between 1983 and 1988 and from 1992 onwards (1980s standardised catch rate: $60.3 \pm 94.7 ; 1990 \mathrm{~s}$ standardised catch rate: $38.4 \pm 81.9$; Figs. 5 \& 6). A Jonckheere-Terpstra 


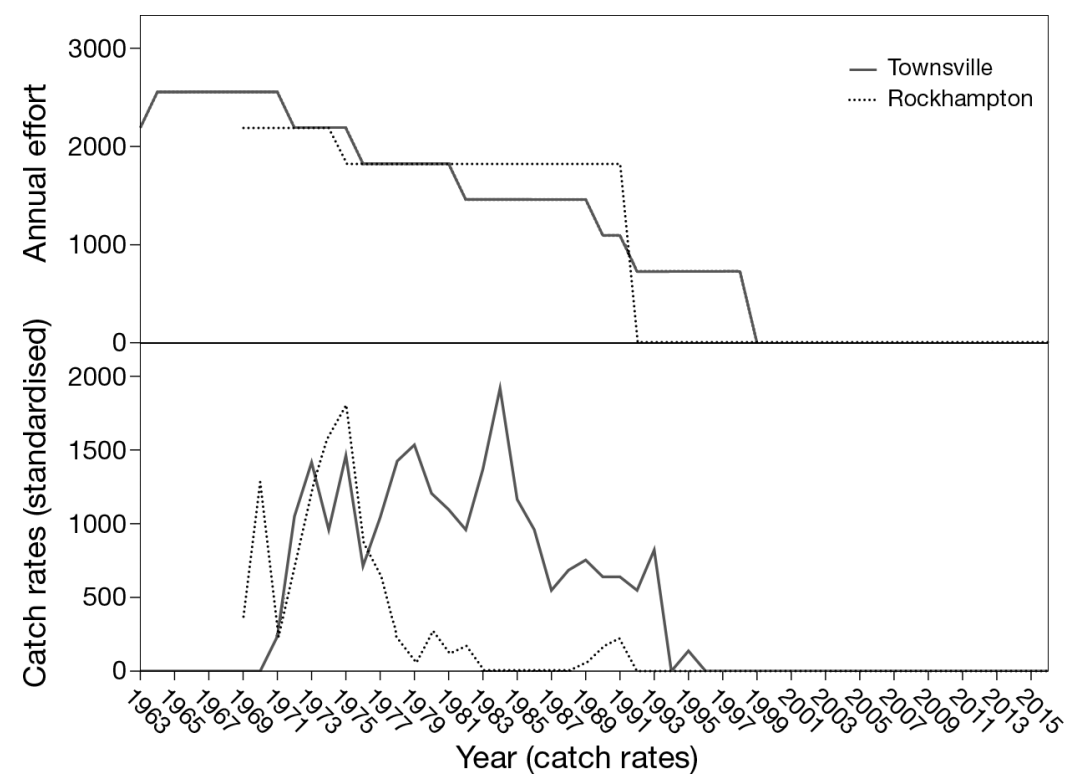

Fig. 5. Queensland Shark Control Program annual fishing effort (gillnet days per year) versus standardised catch rate $\left(10^{5}\right.$ annual captures per annual gillnet days) for sawfishes in 2 Queensland areas, Townsville and Rockhampton. In Townsville, the program commenced in 1963; in Rockhampton it commenced in 1969

test for ordered alternatives indicated that there was a significant trend of decreasing standardised catch rates over the decades off Rockhampton $\left(T_{\mathrm{JT}}=119.5\right.$, $z=-4.927, \mathrm{p}<0.01)$.

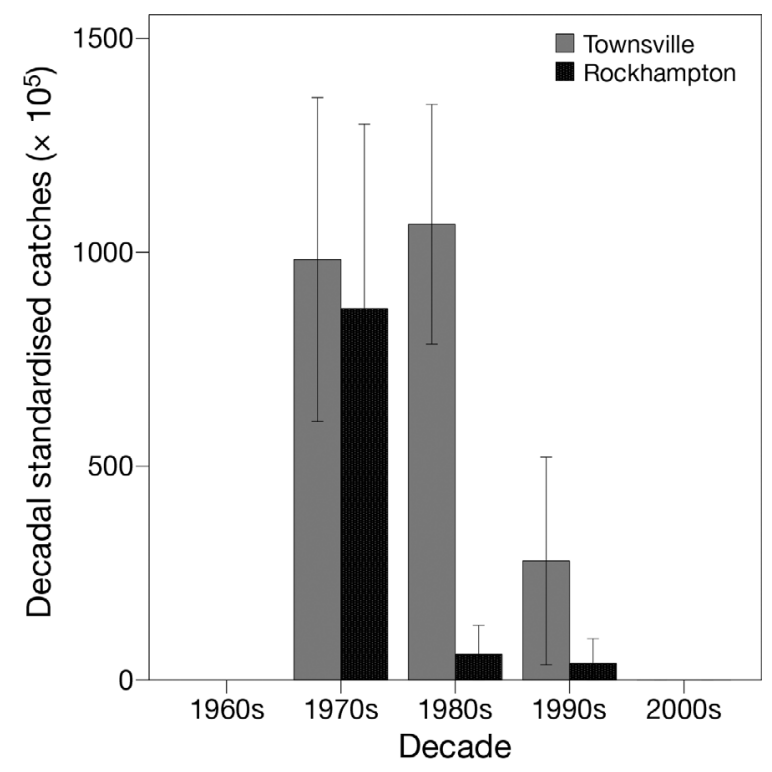

Fig. 6. Mean $( \pm 95 \% \mathrm{CI})$ decadal standardised catches (values were multiplied by $10^{5}$ for ease of presentation) in gillnets for 2 areas, Townsville and Rockhampton. Sawfish captures in the Queensland Shark Control Program declined over the years in both areas, peaking in Townsville in the 1980s and in Rockhampton in the 1970 s

\section{DISCUSSION}

The data set of sawfish captures in the QSCP since 1963 is unique and of high conservation value with regards to our knowledge of the distributions and declines of sawfishes in Queensland's waters. Over the decades that the QSCP has been active, detail in data collection has increased, and so has the focus on species identification and by-catch reduction (Gribble et al. 1998). Unfortunately, many sawfish captures during the first decades of the program lacked biological information, such as species, size or sex, although this was routinely collected for target species such as tiger sharks Galeocerdo cuvier (Simpfendorfer 1992).

The data set does not allow quantification of relative abundance of sawfishes across all areas where QSCP gear was deployed, but analysis of simple presence/absence data indicates that relative abundances of sawfishes declined towards the south. Even in the years since 1996, the most northern area (Cairns) recorded the most sawfish captures (see Fig. 3). Before 1996, sawfishes were captured in large numbers in the 4 northern areas, but after 1996 they were only caught in the 3 most northern areas. In the 6 southern areas, sawfishes were only caught in small numbers before 1996. Sawfishes were never caught in Brisbane/North Stradbroke Island, which is likely due to the fact that the QSCP gear was located in the clear waters on the east coast of North Stradbroke Island, and not on the west coast of the island, which would have placed the gear inside Moreton Bay. Moreton Bay is a shallow embayment that could present habitat suitable for sawfishes. It is possible that the current distributions of sawfishes are now restricted to coastlines with low human density, such as north of Cairns, but further assessments are needed.

Since 1996, the use of shark meat as bait increased compared to mullet bait, to decrease captures of bycatch such as dolphins and turtles on drum lines (Department of Primary Industries and Fisheries 2006). Contractor notes taken since 1996 indicate that 2 narrow sawfish Anoxypristis cuspidata found dead on drum lines off Cairns in 2002 and 2003 were used as bait. The notes also indicate that a further $19 \operatorname{dead} A$. cuspidata were towed out to sea and dumped. The author recommends that in the future, samples are 
made available to scientists. However, the use of shark meat instead of mullet bait on drum lines is likely to affect or reduce by-catch of sawfishes, as at least largetooth sawfish Pristis pristis often refuse any food other than mullet during the process of acclimation to captivity (pers. obs.), but more data are needed.

QSCP data after 1996 indicate that a majority of sawfishes were captured near the bottom of gillnets. Since 1962/1963, nets were surface-set to not reach the substrate, as initially bottom-set nets resulted in high by-catches of rays, which in turn inflicted gear loss as sharks mauled the nets (Gribble et al. 1998). Data of capture distance from the bottom are currently not available, but these data could help prevent future sawfish catches through indication of how far sawfishes travel into the water column. For example, sawfishes are considered to be benthic, but analysis of the food capture behaviour of captive $P$. pristis indicates that they can use the whole water column for prey manipulation (Wueringer et al. 2012). Importantly, data from surface-set gillnets are likely to underestimate local relative abundances of sawfishes.

Until 1996, the data set contains many duplicates. Detailed analysis (see Supplement 2) does not allow firm conclusions as to whether they comprise valid data entries of multiple sawfish being caught in a single day, or invalid data entries that were duplicated over the years. However, by far the highest number of duplicates occurred in a single location off Townsville, namely Horseshoe Bay, Magnetic Island. The QSCP gear was set and checked by a single contractor in the Townsville area from 1964 to 1986 (Simpfendorfer 1992), who recorded many biological parameters (e.g. sex, TL, sexual maturity, number of embryos, stomach contents) for at least one target species, G. cuvier. It cannot be excluded that data duplication could have occurred at a later stage, but it is likely that at least on some occasions, multiple sawfishes were caught in a single net on a single day. This is strengthened by the fact that sawfish - especially juveniles - have been observed to rest in groups and multiple animals have been caught together (smalltooth sawfish $P$. pectinata: see Seitz \& Poulakis 2002; P. pristis: B. E. Wueringer unpubl. data, S. Peverell pers. comm.).

The delayed peaks of sawfish captures after program commencement in Mackay (Fig. 2) and Townsville (Fig. 5) are likely correlated with the annual effort of the QSCP for these years. No annual effort was calculated for Mackay, as it remains unknown in which gear most sawfishes were caught in the first decade. The QSCP data indicated that at the begin- ning of the program, 'apparatus was only deployed in December and January, from Friday until Monday', but it is unknown when this was switched to full time, year-round gear deployment (J. Krause pers. comm.). For Townsville, discrepancies in gear deployment details were found between the QSCP data and data obtained by Simpfendorfer (1992), who notes that prior to 1968, QSCP gear deployed off Townsville

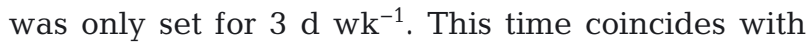
negligible sawfish captures; however, the data set provided by the QSCP indicate that gillnets were set around the clock.

The QSCP data indicate, with all limitations taken into account, that the majority of sawfishes were caught in gillnets and only a small percentage were caught on drum lines. In Cairns, Townsville and Rockhampton, the lack of sawfish catches in the QSCP in the last years coincides with the ban of gillnets. In Gladstone, which is located only $100 \mathrm{~km}$ south of Rockhampton, drum lines were the only gear type ever used in the QSCP and no sawfish have ever been caught.

\section{Survival rates}

As the majority of sawfishes captured by the QSCP were reported 'Alive', QSCP practices do not appear to be detrimental to sawfishes during the period of capture. During the early years of the program, sawfishes were not protected, but contractors were generally encouraged to release by-catch alive (J. Krause pers. comm.). Since the 1990s, when by-catch management became more important in the program, 'Alive' very likely means that animals were released alive, and since 2001, releases were noted in the comments section. The QSCP data clearly indicate that sawfishes can survive capture in gillnets. This is likely due to the fact that batoids are not obligate RAM ventilators and thus do not depend on a swimming motion to ventilate their gills.

\section{CONCLUSIONS}

The successful management of remnant sawfish populations, in Queensland waters and globally, depends largely on the management of gillnet fisheries. As the majority of sawfishes captured in the QSCP gillnets were encountered alive, the impact of this fishing method on sawfish populations can be managed. Gillnet fishers need to check their nets regularly and be trained in quick sawfish release 
procedures that cause minimal damage to the animal, people and fishing gear. Fishers also need to understand that amputating a saw likely causes a slow death by starvation, as the saw does not grow back (Morgan et al. 2016). Given that gillnets used in the QSCP were surface-set and thus likely underestimate current relative abundances of sawfishes, and their use has been reduced over time to reduce bycatch, assessment of current sawfish populations along the Queensland coast will require fisheries-independent sampling. The use of gillnets by scientists is likely the most effective way to capture sawfish. The QSCP should make samples of dead sawfishes available to scientists in the future. Moreover, more detailed data collection of biological parameters (e.g. species ID with images, length, capture location, depth) is recommended for these endangered species.

Acknowledgements. This analysis is part of a larger project on the distribution, relative abundances, and ecology of sawfishes in Queensland conducted by Sharks And Rays Australia. The study was funded by Save Our Seas Foundation (Switzerland) grant numbers 278 and 309. I thank Jeff Krause, the current Manager of the Queensland Shark Control Program, Department of Agriculture and Fisheries, for providing the data used in this study. Use of the Shark Control Program data is by courtesy of the State of Queensland, Australia, through the Department of Agriculture and Fisheries. I also thank the 3 anonymous reviewers and Gregg Poulakis for improving earlier versions of the manuscript. This work was presented as part of the symposium 'Biology and Ecology of Sawfishes' at the 2016 annual meeting of the American Elasmobranch Society, which was supported by funding from the Save Our Seas Foundation, Disney Conservation Fund, and the American Elasmobranch Society.

\section{LITERATURE CITED}

Beaman RJ (2010) Project 3DGBR: a high-resolution depth model for the Great Barrier Reef and Coral Sea. Marine and Tropical Sciences Research Facility (MTSRF) Project 2.5i.1a Final Report. MTSRF, Cairns

Department of Primary Industries and Fisheries (2006) A report on the Queensland Shark Safety Program. Queensland Government, Department of Primary Industries and Fisheries, Brisbane. www.dpc.wa.gov.au/Consultation/ Documents/Appendix \% 2014\%20A\%20Report\%20on \% 20 the $\% 20$ Queensland $\% 20$ Shark $\% 20$ Safety $\% 20$ Program.pdf

Department of the Environment (2014) Draft issues paper for sawfish and river sharks. Australian Government Department of the Environment, Canberra. www.environment. gov.au/system/files/resources/39d19c4b-90db-438b-b1e96b6195988d69/files/draft-issues-paper-sawfish-and-riversharks.pdf

Dulvy NK, Fowler S, Musick JA, Cavanagh RD and others

Editorial responsibility: Gregg Poulakis (Guest Editor), Port Charlotte, Florida, USA
(2014) Extinction risk and conservation of the world's sharks and rays. eLife 3:e00590

*Dulvy NK, Davidson LNK, Kyne PM, Simpfendorfer CA, Harrison LR, Carlson JK, Fordham SV (2016) Ghosts of the coast: global extinction risk and conservation of sawfishes. Aquat Conserv 26:134-153

Environmental Protection and Biodiversity Conservation Act (1999) Australia. Office of Legislative Drafting and Publishing, Canberra. https://www.legislation.gov.au/Details/ C2005C00338 (accessed June 2016)

GBRMPA (Great Barrier Reef Marine Park Authority) (2012) A vulnerability assessment for the Great Barrier Reef: sawfish. Great Barrier Reef Marine Park Authority, Townsville. http://elibrary.gbrmpa.gov.au/jspui/bitstream/11017/ 2947/1/gbrmpa-VA-Sawfish-11-7-12.pdf

Gribble NA, McPherson GR, Lane B (1998) Effect of the Queensland Shark Control Program on non-target species: whale, dugong, turtle and dolphin: a review. Mar Freshw Res 49:645-651

* Harry AV, Tobin AJ, Simpfendorfer CA, Welch DJ and others (2011) Evaluating catch and mitigating risk in a multispecies, tropical, inshore shark fishery within the Great Barrier Reef World Heritage Area. Mar Freshw Res 62: 710-721

* Holmes BJ, Sumpton W, Mayer D, Tibbetts IR, Neil DT, Bennett MB (2012) Declining trends in annual catch rates of tiger shark (Galeocerdo cuvier) in Queensland, Australia. Fish Res 129-130:38-45

IUCN (2006) 2006 IUCN Red List of Threatened Species. www.iucnredlist.org (accessed July 2006)

* Morgan DL, Wueringer BE, Allen MG, Ebner BC, Whitty JM, Gleiss AC, Beatty SJ (2016) What is the fate of amputee sawfish? Fisheries (Bethesda, Md) 41:71-73

Paterson RA (1990) Effects of long-term anti-shark measures on target and non-target species in Queensland, Australia. Biol Conserv 52:147-159

Peverell SC (2005) Distribution of sawfishes (Pristidae) in the Queensland Gulf of Carpenteria, Australia, with notes on sawfish ecology. Environ Biol Fishes 73:391-402

Peverell SC (2009) Sawfish (Pristidae) of the Gulf of Carpentaria, Queensland, Australia. MSc thesis, James Cook University, Townsville

Queensland Fisheries Act (1994) Australia. OQPC, Brisbane. https://www.legislation.qld.gov.au/view/html/inforce/ current/act-1994-037 (accessed June 2016)

Seitz JC, Poulakis GR (2002) Recent occurrence of sawfishes (Elasmobranchomorphi: Pristidae) along the southwest coast of Florida (USA). Fla Sci 65:256-266

Seitz JC, Poulakis GR (2006) Anthropogenic effects on the smalltooth sawfish (Pristis pectinata) in the United States. Mar Pollut Bull 52:1533-1540

* Simpfendorfer CA (1992) Biology of tiger sharks (Galeocerdo cuvier) caught by the Queensland Shark Meshing Program off Townsville, Australia. Aust J Mar Freshwater Res 43:33-43

Wueringer BE, Squire LJ, Collin SP (2009) The biology of extinct and extant sawfish (Batoidea: Sclerorhynchidae and Pristidae). Rev Fish Biol Fish 19:445-464

*Wueringer BE, Squire L Jr, Kajiura SM, Hart NS, Collin SP (2012) The function of the sawfish's saw. Curr Biol 22: R150-R151

Submitted: October 2, 2016; Accepted: August 2, 2017 Proofs received from author(s): October 5, 2017 